\title{
Rainfall trend analysis and its future projection over Gangetic West Bengal (GWB) region of India during post-monsoon and winter season
}

\section{Pramiti Kumar Chakraborty* and Lalu das}

Department of Agriculture Meteorology \& Physics, Bidhan Chandra Krishi Viswavidyalaya, Mohanpur, Nadia (West Bengal),INDIA

*Corresponding author. Email: pramitikumar27@gmail.com

Received: October 28, 2015; Revised received: April 16, 2016 ; Accepted: July 05, 2016

Abstract: Studying the variability of rainfall and its future projection during post-monsoon and winter season is important for providing the information to the farmers regarding crop planning. For evaluating rainfall scenario, long (1901-2005) and short term (1961-2005 and 1991-2005) rainfall data of nine selected IMD stations of South Bengal was collected and subdivided into 30 year period up to 1990 and a 15 year period from 1991 to 2005. The data were subjected to trend analysis and available GCM data were compared with the observed rainfall data. The postmonsoon and winter rainfall changes during 1901-2005 were positive (except Krishnangar, $-47.67 \mathrm{~mm}$ ) and negative (except Alipore and Berhampur) respectively. During 1991-2005 all the stations recorded a positive change during post-monsoon, while reverse was true for winter. Among the different GCMs, INGV-ECHM4 estimated the postmonsoon rainfall at the best, whereas winter rainfall successfully estimated by MIROC-Hi. Future projection of both post-monsoon and winter rainfall over the region showed an increasing trend. This will help in policy formulation for water management in agriculture.

Keywords: Gangetic West Bengal, GCMs, Post-monsoon, Rainfall, Winter

\section{INTRODUCTION}

The GWB is the granary of the state. The $70 \%$ of agricultural land depends on rainfall. The rainfall during post-monsoon and winter season plays an important role for raising a large number of crops in the area which lacks irrigation facilities. Moreover, a caveat has been sounded by environmental activist on arsenic pollution because of over exploitation of ground water in the Gangetic Plains of West Bengal(Mukhopadhyay and Sanyal, 2004; Das et al.,2005). Under this situation study of rainfall pattern and its future projection should be the priority of agroclimatic research. Variability pattern in rainfall is greatly important for agricultural activities. Several authors analyzed the assured distribution of weekly rainfall at a specified probability level for identifying the crop growing seasons in GWB (Chakraborty 1990, Chakraborty et al., 1990, Chakraborty and Chakraborty 1991 ). Srivastava et al., (1992) analyzed the decadal trends of rainfall over India. . Lohar and Pal (1995) examined the modification of climatic variables due to change in land use pattern during the pre-monsoon season over Southern part of West Bengal. A few authors (De 2001, Kolli et al., 2002 Rupa Kumar et al., 2002 , Dash and Rao 2003 , Prakas Rao et al., 2004 , Kothawale and Rupa Kumar 2005 ) studied the climatic changes using observed data as well as model results.. Das and Lohar (2005) investigated the climate change information over GWB using General Circulation Models (GCMs).
Dash et al., (2007) observed that the amount of rainfall is decreasing in different seasons. Patra et al., (2012) examined the long term changes in rainfall characteristics by using parametric and non-parametric tests over Odisha. Mehrotra et al., (2013) projected an increase in pre-monsoon and post-monsoon rainfall over Karnataka. Parth Sarathi et al., (2015) compared the rainfall pattern in Gangetic Plains of India through different simulation models.

The present study centered on the trend analysis of rainfall and its future projection during post-monsoon and winter season in Gangetic West Bengal. The information will be helpful to the farming community to frame their cropping programme during this period.

\section{MATERIALS AND METHODS}

The present study has been carried out over the state of West Bengal with a special focus on Gangetic belt. The state is situated in eastern part of the country between coordinates $21^{\circ} 20^{\prime} \mathrm{N}$ to $27^{\circ} 32^{\prime} \mathrm{N}$ and $85^{\circ} 50^{\prime} \mathrm{E}$ to $89^{\circ} 52^{\prime} \mathrm{E}$. Nine IMD stations are selected, most of which lie in the southern districts of West Bengal (Table 1). We considered our study domain extending from $20-26^{\circ} \mathrm{N}$ and $83-89^{\circ} \mathrm{E}$ where all available GCMs grid points are located.

Two types of data are used in this study, namely, observed station data from IMD Kolkata and the CMIP3 GCMs outputs downloaded from the Program for Climate Model Diagnosis and Intercomparison (PCMDI) 
archive (www-pcmdi.llnl.gov/ipcc/about_ipcc.php). Two types of simulations namely the $20^{\text {th }}$ century run and A1b scenarios were used in this present study. Six GCMs viz.INGV-ECM4, MIROC-Hi, CNRM, GISS, MPI etc. are used for the present study (Table 2).

The rainfall data, collected from IMD were scrutinized, five stations have the data set of 1901-2005 and the remaining four stations have the data set from 1961 -2005 .

Nine IMD stations located in the southern districts of West Bengal were selected for the present study. Among the nine stations, Alipore, Krishnagar, Sagar Island, Midnapore and Berhampore have the database for the period 1901-2005; Bankura, Contai and Shantiniketan have the database for the period 19612005 and Holdia has the database for 1991-2005 (Table 1). Two types of data were used in this study namely observed station data, which was collected from Regional Meteorological Centre, Kolkata, and the GCM outputs downloaded from the Programme for Climate Model Diagnosis and Inter comparison archive (PCMDI) on the web link www-pcmdi.llnl.gov/ ipcc/about_ipcc.php. Six GCMs namely INGVECHM4, UKMO-HaDCM3, MIROC-Hi, CNRM, GISS and MPI were used in the present study. Two types of simulations namely the $20^{\text {th }}$ century run and A1b scenarios were used in the present investigation. The characteristics of the model are given in Table 2 . Two types of analysis were performed: the long-term analysis using the data for the period of 1901-2005 and short-term analysis with 30 years period that comprised of 1901-1930, 1931-1960, 1961-1990 and 19912005 within the long-term period. To test the accuracy of the model simulation with observations, selected few statistical indices as listed in Table 3 were calculated for the purpose of GCMs validation.

\section{RESULTS AND DISCUSSION}

To detect the observed rainfall change signal over GWB, we analyzed the linear trends for a long term period as well as short term period. During postmonsoon season the rainfall change is positive for all the major IMD stations (Table 4) except Krishnagar. During 30 year cycle upto 1990, Alipore and Midnapore recorded a positive trend in pos-monsoon rainfall. However Krishnanagar, Sagar Island and Berham-

Table 1. Distribution of stations along with time series

\begin{tabular}{llll}
\hline Latitude & Longitude & Station Name & Data period \\
\hline 22.53 & 88.33 & Alipore & $1901-2005$ \\
23.4 & 88.52 & Krishnanagar & $1901-2005$ \\
21.65 & 88.05 & Sagarisland & $1901-2005$ \\
22.42 & 87.32 & Midnapur & $1901-2005$ \\
24.13 & 88.27 & Berhampur & $1901-2005$ \\
23.23 & 87.07 & Bankura & $1961-2005$ \\
21.78 & 87.75 & Contai & $1961-2005$ \\
23.67 & 87.7 & Shantineketan & $1961-2005$ \\
22.03 & 88.06 & Holdia & $1991-2005$ \\
\hline
\end{tabular}

pur recorded a negative trend during 1961-90, 1931-90 and 1961-90 respectively. During 1961-90, Bankura, Contai and Shantiniketan recorded a negative change in post-monsoon season rainfall. During 1991-2005, all the nine stations recorded a positive change in postmonsoon rainfall. Increasing trend of post-monsoon rainfall has also been reported by Dash et al., (2007) and Venkatesh et al.,(2008) in some parts of India. However, Patra et al.,(2012) reported an overall decreasing trend of post-monsoon rainfall in Odisha, although a $6.2 \%$ increase in post-monsoon rainfall was observed by the authors during the last 10 year study. Contribution of rainfall in October and post-monsoon season increased considerably in Kolkata and S24P districts, observed by Pal et al., (2015). Post-monsoon rainfall has great impact on agricultural activities. Heavy rainfall during October-November delays the sowing of wheat (Parya et al., 2010). Decreasing trend in annual rainfall was also reported by Patle and Libang (2014) in North-East India. The authors observed significant negative trend during pos-monsoon season.

The long term linear trend analysis shows that Alipore and Berhampore recorded the positive change while the remaining three stations recorded a negative change in winter rainfall (Table 5). In the present study it was observed that the winter rainfall is showing a negative trend from 1991 onwards (Table 5). Patra et al., (2012) observed that the linear trend for winter rainfall was nearly constant but there was $17.1 \%$ decrease in the mean rainfall of last 10 year over normal in Odisha. The variability in winter rainfall has an important impact on agricultural crops. The negative trend in winter rainfall may invite lower productivity of wheat and winter pulses and oilseeds. In Hooghly district, the assured rainfall at $75 \%$ probability level during winter is less than $5 \mathrm{~mm}$ and $\mathrm{AE} / \mathrm{PE}$ value is approximately 0.69 (database 1920-1985, Chinsurah). This led to facilitate the sowing of winter pulses and oilseeds during middle of November (Chakraborty et al.,1990).

GCMs validation: Regional averaged seasonal observed rainfall using five major IMD stations were computed along with regional average of each GCM simulation using available grid points over GWB and its neighbourhood region. We have computed the observed as well as model simulated rainfall trends during the period of 1901-2005 for post-monsoon and winter seasons (Table 6). Rainfall is showing a decreasing trend in winter season to an extent of $\sim 1.49$ $\mathrm{mm}$ for 105 years. The GCMs are also showing a decreasing trend of winter rainfall except INGVECHM4. But other five models over estimate the decreasing trend of winter rainfall change except GISS. Testing the accuracy of rainfall simulation: We have tested the accuracy of model simulation with observation through some statistical measures (indices). We have computed all the parameters season wise us- 
Table 2. Different GCMs used in the study.

\begin{tabular}{|c|c|c|c|}
\hline Model ID & Modelling Centre & Atmospheric Resolution & Oceanic Resolution \\
\hline INGV-ECHAM4 & $\begin{array}{l}\text { Max Plank Institute For Meteorol- } \\
\text { ogy,Germany }\end{array}$ & $1.125^{\circ} \times 1.125^{\circ}$ & $2^{\circ} \times 2^{\circ} \mathrm{L} 31$ \\
\hline UKMO-HADCAM3 & $\begin{array}{l}\text { Hadley Centre For Climate Predic- } \\
\text { tion and Research,UK }\end{array}$ & $2.5^{\circ} \times 3.75^{\circ}$ & $1.25^{\circ} \times 1.25^{\circ} \mathrm{L} 20$ \\
\hline MIROC-Hi & JAMSTEC, Japan & T106 L56 & $0.2^{\circ} \times 0.3^{\circ} \mathrm{L} 47$ \\
\hline CNRM & $\begin{array}{l}\text { Centre National de Recherches } \\
\text { Météorologiques, } \\
\text { France. }\end{array}$ & T63 L45 & $0.5-2^{\circ} \times 2^{\circ} \mathrm{L} 31$ \\
\hline GISS & $\begin{array}{l}\text { Goddard Institute for Space Stud- } \\
\text { ies,USA }\end{array}$ & $4^{\circ} \times 5^{\circ}$ & $4^{\circ} \times 5^{\circ} \mathrm{L} 13$ \\
\hline MPI & $\begin{array}{l}\text { Max Plank Institute For Meteorology, } \\
\text { Germany }\end{array}$ & $\begin{array}{l}1.9^{\circ} \times 1.9^{\circ}(\mathrm{T} 63) \\
\mathrm{L} 31\end{array}$ & $1.5^{\circ} \times 1.5^{\circ}$ \\
\hline
\end{tabular}

Table 3. Description of statistical measures (Where $\mathrm{M}=$ Model output, $\mathrm{M}=$ Mean of the Model output, $\sigma_{\mathrm{M}}=$ standard deviation of the Model output, $\mathrm{O}=$ observations, $\overline{\mathrm{O}}$ $=$ mean of the observations, $\sigma_{O}=$ standard deviation of the observations and $\mathrm{N}=$ number of year)

\begin{tabular}{ll}
\hline Name of indices & Equations \\
\end{tabular}

ing standard equations for each model and a multi model ensemble (MME6) using six GCMs. The performance of the model was tested on the basis of the values of the computed indices. During post-monsoon season the INGV-ECHM4 is showing higher D-Index with lower NTRMSE and positive MB values (Table 7). This suggests that the model estimates the observed rainfall in the post-monsoon season very closely. The MIROC-Hi shows a high D-Index and $R$ values with low NTRMSE which indicate a close association with the observed and simulated winter rainfall data whereas CNRM model is showing very poor performance (Table 8).

Projected change in rainfall during 2001-2050 over GWB: The future projection of rainfall scenario is based on five GCMs along with a multi model ensemble (MME5) (Fig. 1) using A1B scenarios. Future rainfall will increase in the post-monsoon season which is similar to the observed trend. During winter the projected rainfall will increase however observed rainfall is showing a decreasing trend. Winter rainfall is increasing in the dry tract of the state West Bengal whereas it is decreasing in the new alluvial zone, but the trend analysis recorded positive and negative change in rainfall. Future projection of winter rainfall shows an increasing trend. Increasing trend of rainfall was observed during post-monsoon season in last fifteen year period. Mehrotra et al., (2013) projected 2\% increase in post-monsoon rainfall by 2055. Das et al.,

Table 4. Linear trends of rainfall change pattern in post-monsoon

\begin{tabular}{llllll}
\hline \multicolumn{7}{c}{ Rainfall change in different time series ( in mm ) } \\
\hline STAION & $1901-2005$ & $1901-30$ & $1931-60$ & $1961-90$ & $1991-2005$ \\
ALIPORE & +55.19 & +15.56 & +1.79 & +19.15 & +118.56 \\
KRISHNANAGAR & -47.67 & +11.03 & +123.59 & -68.57 & +143.13 \\
SAGAR ISLAND & +17.61 & +39.57 & -27.16 & -49.50 & +47.31 \\
MIDNAPUR & +6.89 & +32.94 & +21.54 & +8.64 & +93.52 \\
BERHAMPUR & +13.71 & +5.91 & +30.55 & -19.07 & +83.58 \\
BANKURA & - & - & - & -6.91 & +16.40 \\
CONTAI & - & - & - & -46.35 & +200.26 \\
SHANTINIKETAN & - & - & - & -23.67 & +69.24 \\
HOLDIA & - & - & - & - & +137.69 \\
Regional averaged & +18.10 & +42.01 & +60.12 & -46.57 & +204.29 \\
\hline
\end{tabular}


Table 5. Linear trends of rainfall change pattern in winter

\begin{tabular}{llllll}
\hline \multicolumn{7}{l}{ Rainfall change in different time series ( in mm ) } \\
\hline STAION & $1901-2005$ & $1901-30$ & $1931-60$ & $1961-90$ & $1991-2005$ \\
ALIPORE & +12.78 & -10.82 & +12.58 & -24.98 & -48.77 \\
KRISHNANAGAR & -13.81 & -21.54 & +15.30 & -13.73 & +31.97 \\
SAGAR ISLAND & -1.97 & +16.38 & +17.46 & -0.07 & -52.65 \\
MIDNAPUR & -16.78 & -38.59 & +17.59 & -12.87 & -30.31 \\
BERHAMPUR & +12.27 & +18.21 & +20.95 & +11.43 & -13.85 \\
BANKURA & & & +13.93 & -28.13 \\
CONTAI & & & +8.21 & -18.67 \\
SHANTINIKETAN & & & & -24.51 \\
HOLDIA & & & & -52.39 \\
Regional averaged & -7.48 & -36.35 & +16.76 & +6.93 & -26.36 \\
\hline
\end{tabular}

Table 6. Validation of different GCM model output with observed total rainfall change (mm) (1901-2005)

\begin{tabular}{|c|c|c|c|c|c|c|c|c|}
\hline \multirow{2}{*}{\multicolumn{2}{|c|}{ SEASON }} & \multirow{2}{*}{$\begin{array}{l}\text { OBSERVED CHANGE } \\
(\mathbf{m m})\end{array}$} & \multicolumn{6}{|c|}{ DIFFERENT MODEL OUTPUT (mm) } \\
\hline & & & $\begin{array}{l}\text { INGV- } \\
\text { ECHM4 }\end{array}$ & $\begin{array}{l}\text { MIROC- } \\
\text { Hi }\end{array}$ & GISS & $\begin{array}{l}\text { UKMO- } \\
\text { HaDCM3 }\end{array}$ & CNRM & MPI \\
\hline \multirow{2}{*}{\multicolumn{2}{|c|}{$\begin{array}{l}\text { POSTMONSOON } \\
\text { WINTER }\end{array}$}} & +18.11 & +21.41 & -14.35 & -6.65 & +1.46 & -53.77 & -19.05 \\
\hline & & -1.49 & +4.69 & -10.67 & -0.44 & -5.14 & -51.29 & -14.25 \\
\hline \multicolumn{3}{|c|}{$\begin{array}{l}\text { Table 7. Showing the statistical values computed be } \\
\text { Statistics }\end{array}$} & GISS & \multicolumn{2}{|c|}{ UKMO-HADCM3 } & CNRM & MPI & MME6 \\
\hline D Index & 0.45 & 0.35 & 0.35 & \multicolumn{2}{|c|}{0.35} & 0.37 & 0.36 & 0.25 \\
\hline $\mathrm{R}$ & 0.09 & -0.05 & 0.12 & \multicolumn{2}{|l|}{-0.12} & 0.05 & -0.11 & 0.02 \\
\hline NTRMSE & 1.35 & 1.18 & 1.02 & \multicolumn{2}{|l|}{1.40} & 2.03 & 1.39 & 1.02 \\
\hline MB & 55.42 & -26.99 & -6.30 & \multicolumn{2}{|l|}{-67.90} & 140.02 & -70.49 & 3.95 \\
\hline
\end{tabular}

Table 8. Showing the statistical values computed between observed and model simulated winter rainfall

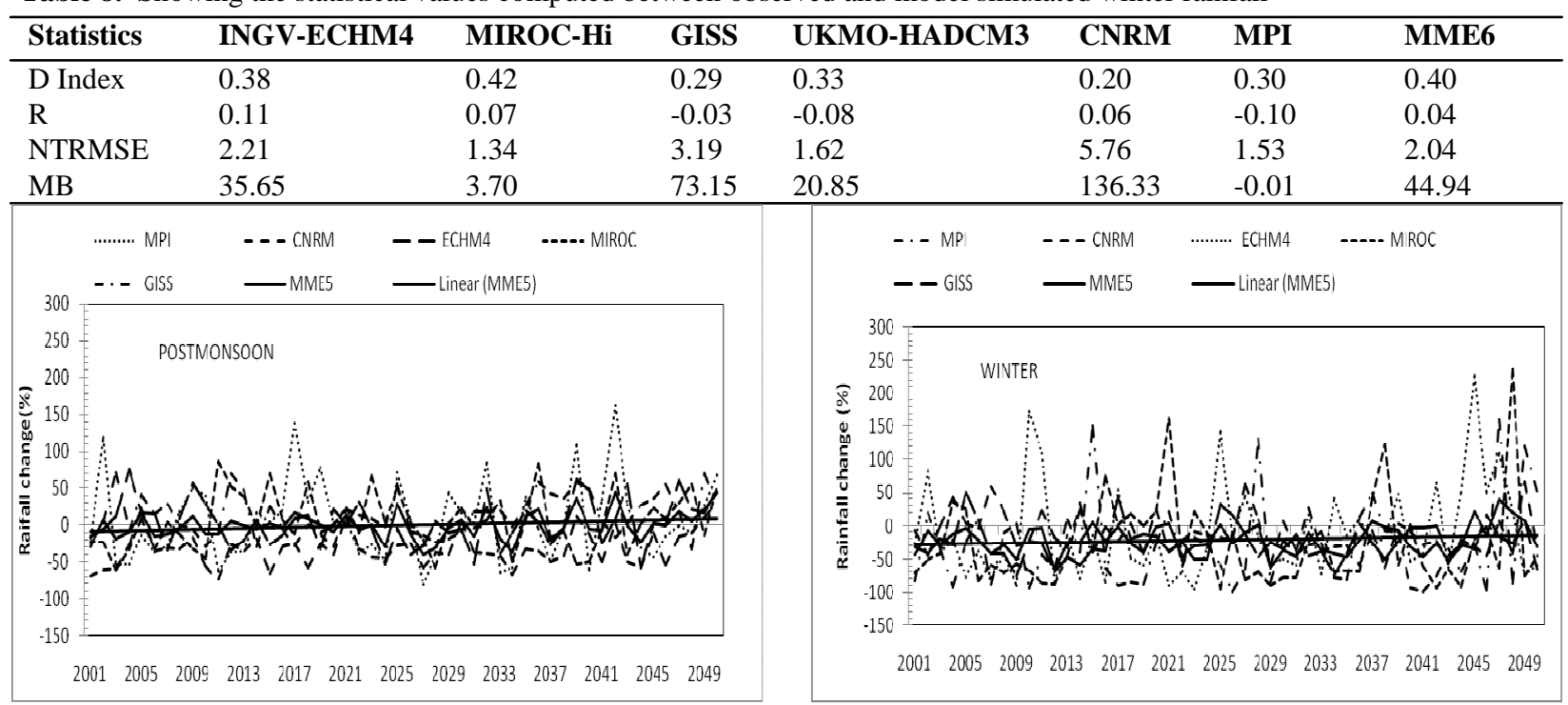

Fig. 1: Projected rainfall change (\%) scenario during 2001-2050 in post-mosoon and winter season over Gangetic West Bengal region.

(2016) observed an increasing rate in winter warming which may increase evaporation from soil and water surface and leads to cloud formation and subsequent rainfall. Present study estimated the past and future rainfall change trend focusing on two important season namely post-monsoon and winter using combined approach of station data as well as latest generation GCM simulation. This most probably the first attempt (except Das and Lohar, 2005) evaluated GCMs performance over GWB region and also construction of projected future rainfall from better per- forming GCMs.

\section{Conclusion}

Present analysis showed that the post-monsoon rainfall recorded a positive trend while the winter rainfall recorded a negative trend during 1991-2005. However the future rainfall will be increasing in both seasons. This information is helpful for farming community to select crop during post-monsoon and winter season along with better water resource management. Although station data indicates winter rainfall is de- 
creased in the last century and post monsoon rainfall has enhanced many fold but future projection indicates the increasing rainfall scenario in both post-monsoon and winter season. The future enhanced amount rainfall in winter mostly arises from winter warming which is very high and rapid. Enhancement of rainfall may invite more occurance of flood in these seasons. Apart from flood occurrences of disease and pest may be more in future due to increased rainfall. But enhanced rainfall in winter season will be beneficial for rabi crops, winter vegetables as well as boro rice cultivation.

\section{AKNOWLEDGEMENTS}

Authors are grateful to the Department of Agricultural Meteorology and Physics, Bidhan Chandra Krishi Viswavidyalaya (BCKV), West Bengal, India for their constant support and advice. Special thanks are also extended to Ms Monami Dutta and Jitendra Kumar Meher for their constant support and encouragement for analyzing GCMs simulations for this work. India Meteorological Department (IMD) and the Program for Climate Model Diagnosis and Intercomparison (PCMDI) are also acknowledged for providing data and archiving the model outputs.

\section{REFRENCES}

Chakraborty, P. K. (1990). Rainfall probability analysis and its importance on agricultural practices for some of the locations of Nadia district, West Bengal. Environment \& Ecology 8:589-593.

Chakraborty, P. K ., Chakraborty, A. K. (1991). Assured rainfall in Nadia district and its effect on cropping pattern. Environment \& Ecology 9: 81-83

Chakraborty, P .K ., Huda, A. K. S ., Chatterjee, B.N ., Khan, S.A. (1990). Rainfall and its impacts on cropping pattern in Hooghly district of West Bengal. Indian Journal of Agricultural Science 60: 101-106.

Das, D.K.,Garai, T.K., Sarkar, S.,and Sur, P.(2005) Introduction of arsenic with zink and organics in a rice cultivated field in India. The Science World Journal 5: 449-456

Das, L. and Lohar, D . (2005). Construction of climate change scenario for a tropical monsoon region. Climate Research 30: 39-52

Das, L.,Dutta, M., Meher, J.K., and Akhtaer, J.(2016). Temperature Change Scenarios over the Chilka Lagoon of India during 1901-2100. Journal of Climate Change 2(1): 1-14

Dash, S K. and Rao, P. (2003). Assessment of climate change in India and Mitigation Policies. W W F - India, New Delhi.

Dash, S. K., Jenamani, R.K., Kalsi, S. R. and Panda, S.K (2007). Some evidence of climate change in twentieth century India. Climate Change 85: 299-321.

De, U. S. (2001) Climate change impact :Regional Scenario. Mausam 52 : 201-212.

Kolli, R. K., Kumar, K. K., Ashrit, R .G., Patwardhan, S .K. and Pant, G .B. (2002). Climate Change in IndiaObservations and model projection. In: "Climate Change and India- Issues, Concerns and Opportunity". ( Eds. Shukla, P .R, Sharma, S .K and Ramanna, P. V) (Tata McGraw Hill Publishing Company Ltd, New Delhi.)

Kothawale, D. R. and Rupa Kumar K. (2005). On the recent changes in surface temperature trends over India. Geophysical Research Letters 32(18): 18714. doi:10.1029/2005GL023528

Lohar, D and Pal, B. (1995). The effect of irrigation on premonsoon season precipitation over South West Bengal. Indian Journal of Climate 8: 2567-2570

Mehrotra, R., Sharma, Ashis., Nagesh Kumara, D. and Reshmidevi, T.V. (2013). Assessing future rainfall projections using multiple GCMs and a multi-site stochastic downscaling model. Journal of Hydrology 488:84-100

Mukhopadhyay, D. and Sanyal, S.K.(2004). Complexation and release isotherm of arsenic in arsenic humic/fulvic equilibrium study. Austrelian Journal of Soil Research 42: 815-824

Pal, S., Mazumdar, D. and Chakraborty, P.K. (2015). District wise trend analysis of rainfall pattern in last century (19012000) over Gangetic region in West Bengal, India. Journal of Applied and Natural Science 7(2) (Accepted)

Parth Sarathi, P., Kumar, Praveen. and Ghosh, Soumik. (2015). Possible future rainfall over Gangetic Plains (GP), India, in multi-model simulations of CMIP3 and CMIP5. Theoratical and Applied Climatology. DOI 10.1007/s00704-015-1447-5

Patle, G.T. and Libang, A.(2014).Trend analysis of annual and seasonal rainfall to climate variability in North-East region of India. Journal of Applied and Natural Science, 6(2):480-483

Patra, J. P., Mishra, A., Singh, R. and Huwanshi, N. S. (2012). Detecting rainfall trends in twentieth century (1871-2006) over Orissa State, India. Climate Change 111: $801-817$

Parya, M., Nath, R., Mazumder, D. and Chakraborty, P.K. (2010). Effect of thermal stress on wheat productivity in West Bengal. Journal of Agrometeorology 12(2): 217-220

Prakas Rao, G. S., Jaswal, A.K., Kumar, M.S. (2004). Effect of urbanization on meteorological parameters. Mausam 55: 429-440

Rupa Kumar, K., Krishna Kumar, K., Pant, G. B. and Srinivasan, G. (2002). Climate Change- The India Scenario. International Conference on Science and Technology Capacity Building for Climate Change. Oct 20-22, New Delhi: 5-17

Srivastava, H. N., Dewan, B. N ., Dikshit, S. K ., Rao, P. G. S ., Singh, S .S and Rao, K .R. (1992). Decadal Trends in climate over India. Mausam 43: 7-20

Venkatesh, H ., Krishnakumar, K ., Aski, S. G ., Kulkarni, S. N. (2008). Impact of Climate Change on Agriculture over northern Karnataka. In: "Climate change and agriculture over India". (Eds. G.S.L.H.V Prasad Rao, G.G.S.N. Rao and Y.S. Ramakrisna). Pp. 114-127 (All india Co-Ordinated Research Project on Agrometeorology, Hyderabad) 